\title{
Age-related changes in responsiveness of rat Leydig cells to hCG
}

\author{
K. Purvis, O. P. F. Clausen and V. Hansson \\ Institute of Pathology, Rikshospitalet, Oslo, Norway
}

\begin{abstract}
Summary. The responsiveness of decapsulated testes and isolated Leydig cell preparations from rats (30-80 days of age) to a constant dose of $3 \mathrm{ng} \mathrm{hCG} / 2 \mathrm{ml}$ was assessed by comparison of the production of testosterone and 'total $17 \beta$-hydroxy androgen' (17 $\beta$-HA). When testosterone secretion was used as the index of response, there was a marked increase in the production with age by decapsulated testes and also by equal numbers of Leydig cells. When 17ß-HA was taken as the response parameter this increase was only marginal for the decapsulated testes and there was an age-dependent decrease when expressed per $10^{6}$ cells. These differences probably reflect changes in the metabolism of testosterone to $5 \alpha$-reduced products with increasing age because $80 \%$ of androgen secreted at 30 days is $3 \alpha$-androstanediol and $86 \%$ is secreted as testosterone at 80 days. We conclude that for studies on hCG responsiveness and the steroidogenic capacity of immature rat Leydig cells (a) testosterone is an inappropriate response parameter and (b) this response undergoes a decrease rather than an increase during prepubertal development.
\end{abstract}

\section{Introduction}

It has been proposed that the responsiveness of the rat Leydig cell to hCG or LH gradually increases throughout sexual development (Odell, Swerdloff, Bain, Wollesen \& Grover, 1974; Odell \& Swerdloff, 1975; Payne, Kelch, Murono \& Kerlan, 1977). However, in these and other studies, the parameter of secretory function has been testosterone, in spite of the many publications demonstrating that at certain ages (25-45 days) the major product of the rat testis is not testosterone but the $5 \alpha$-reduced derivatives of testosterone, especially $5 \alpha$-androstan-3 $\alpha, 17 \beta$-diol (Nayfeh, Barefoot \& Baggett, 1966; Steinberger \& Ficher, 1968; Strickland, Nayfeh \& French, 1970; Coffey, French \& Nayfeh, 1971; Ficher \& Steinberger, 1971; Matsumoto \& Yamada, 1973). It therefore seems likely that the magnitude of the Leydig cell response to LH has been grossly underestimated at certain ages because the testosterone produced was metabolized into other compounds and not measurable. The purpose of the present study was to re-examine the in-vitro steroidogenic capacity and hCG responsiveness of testes from rats of different ages by using testosterone secretion and 'total 17 $\beta$-hydroxy androgen' (17 $\beta$-HA) secretion as the response parameters.

\section{Materials and Methods}

\section{Incubation of decapsulated testes}

At the ages of 30, 40,60 and 80 days, groups of 5 Sprague-Dawley rats were killed. The decapsulated testes were placed in glass incubation vials containing $2 \mathrm{ml}$ Dulbecco's medium and incubated in a Dubnoff shaking incubator $(110$ cycles $/ \mathrm{min})$ for $30 \mathrm{~min}$ at $34^{\circ} \mathrm{C}$ in $95 \% \mathrm{O}_{2}+5 \% \mathrm{CO}_{2}$. One of each pair of testes was then exposed to $3 \mathrm{ng}$ hCG (NIAMDD, Bethesda, Maryland; batch CR-119); an equivalent volume $(0.1 \mathrm{ml})$ of $0.9 \%(\mathrm{w} / \mathrm{v}) \mathrm{NaCl}$ was added to the incubation medium of the second testis which was used to determine basal steroid production. Several previous unpublished studies had shown that this concentration of hCG elicits a submaximal androgen response from rat Leydig cells. At intervals of $1 \mathrm{~h}$, for $4 \mathrm{~h}$, aliquots $(0 \cdot 1 \mathrm{ml})$ of the incubation medium were removed, centrifuged to 
remove cellular debris and stored at $-20^{\circ} \mathrm{C}$ until assay. In a second study, the testes from five 30-dayold rats which had been hypophysectomized for 5 days were incubated with or without hCG as described above.

\section{Incubation of Leydig cell suspensions}

The technique used to prepare dispersed Leydig cells was essentially that of Moyle \& Ramachandran (1973) with little modification. Briefly, 6-8 decapsulated testes from rats aged 30, 40,50 or 60 days were incubated for $20 \mathrm{~min}$ at $37^{\circ} \mathrm{C}$ in $10 \mathrm{ml}$ Dulbecco's medium containing $0.1 \%$ collagenase (Sigma Chemical Company, St Louis, Missouri). Incubations were performed in capped polypropylene centrifuge tubes $(50 \mathrm{ml})$ which were shaken $(100 \mathrm{cycles} / \mathrm{min})$ with their long axes parallel to the direction of movement. Interstitial cells were then isolated from the tubular elements by adding $40 \mathrm{ml}$ $0.9 \%(\mathrm{w} / \mathrm{v}) \mathrm{NaCl}$ to each tube, inverting the tubes several times and aspirating the supernatants containing the interstitial cells after the samples had stood for $5 \mathrm{~min}$ at room temperature. After centrifugation at $80 \mathrm{~g}$ for $10 \mathrm{~min}$, each pellet was gently resuspended in medium containing $0.2 \% \mathrm{BSA}$ and $0.07 \%$ Soya bean trypsin inhibitor (Sigma Chemical Company) and filtered through a conical nylon filter (pore size $70 \mu \mathrm{m}$ ). Aliquots of the filtered medium were then taken for determination of the number of interstitial cells and for $3 \beta$-hydroxysteroid dehydrogenase ( $3 \beta$-HSD) staining. Smears were also taken for an assessment of the percentage of typical (morphologically normal) Leydig cells in each preparation. Larger aliquots $(2 \mathrm{ml})$ were incubated, in duplicate, in the presence or absence of hCG $(3 \mathrm{ng})$ after a preincubation period of $30 \mathrm{~min}$ at $34^{\circ} \mathrm{C}$. Aliquots $(0.1 \mathrm{ml})$ of the incubation medium were taken every hour for $4 \mathrm{~h}$, centrifuged and the supernatants were stored at $-20^{\circ} \mathrm{C}$.

The method of determining the percentage of interstitial cells involves the use of microflow fluorometry (Clausen, Purvis \& Hansson, 1978). Cells are stained with a fluorochrome (e.g. ethidium bromide) and they take up fluorescence in proportion to their DNA content. The DNA distribution pattern for the suspensions is then determined with a pulse cytophotometer. By using the number of haploid cells in the suspension as an index of tubular contamination, the percentage of interstitial cells present can be derived.

Histochemical localization of $3 \beta-H S D$ in Leydig cell suspensions was achieved by using the method of Levy, Deane \& Rubin (1959) with some modification. The staining medium consisted of nitroblue tetrazolium $(0.014 \%)$, nicotinamide $(0.016 \%)$ and NAD $(0.027 \%)$ in a modified KrebsRinger buffer $\left(0 \cdot 12 \mathrm{M}\right.$-phosphate buffer, $\mathrm{pH} 8 \cdot 0$, containing $0.21 \mathrm{M} \mathrm{NaCl}$ and $\left.\mathrm{MgSO}_{4}\right)$. The steroid substrate which gave the most pronounced staining was 4 -androsten- $3 \beta$-ol, 17 -one $(0.003 \%$ dissolved to $0.4 \%$ in dimethyl formamide). An aliquot of the Leydig cell suspension $(0.5 \mathrm{ml})$ was incubated with an equal volume of staining medium in capped plastic tubes for $30-60 \mathrm{~min}$ at $37^{\circ} \mathrm{C}$ in a Dubnoff shaker ( $100 \mathrm{cycles} / \mathrm{min})$. A control was similarly incubated with medium containing all the ingredients except the steroid substrate. The total number of nucleated cells and the percentage of 3ß-HSD stained cells was determined on an aliquot of the cell suspension by using a Bürker counting chamber. Under these conditions, background staining in the controls was always negligible.

An assessment of the number of 'typical' Leydig cells, based on morphology, was also carried out in case the $3 \beta$-HSD staining had not detected all of the Leydig cells responding to hCG. Smears of the suspension were then fixed in absolute methanol for $20 \mathrm{~min}$ and stained with May-Grünewald Giemsa. Leydig cells were recognized on the basis of their size and shape, the often eccentric position of the nucleus, the coarse nuclear chromatin, the presence of nucleoli, the vacuolar and/or granular cytoplasm and the eosinophilic nature of their cytoplasm.

\section{Assay of testosterone and 17ß-hydroxy androgens}

Aliquots $(0 \cdot 1 \mathrm{ml})$ of medium from incubations of decapsulated testes and Leydig cell suspensions were extracted with diethyl ether $(1.0 \mathrm{ml})$. The organic phase was transferred to another tube and evaporated under nitrogen. The recovery of tritiated steroids in a parallel extraction was never less than $95 \%$. The residue, redissolved in phosphate buffer, was heated at $60^{\circ} \mathrm{C}$ for $5 \mathrm{~min}$ and vortexed for $15 \mathrm{sec}$. The volume of buffer used to dissolve the residue varied according to the quantity of 
Table 1. Specificities of the antisera raised to testosterone-3-oxime-BSA and $5 \alpha$-androstan-3a,17ß-diol-3-hemisuccinate-BSA

\begin{tabular}{|c|c|c|}
\hline \multirow[b]{2}{*}{ Steroid } & \multicolumn{2}{|c|}{ Cross-reaction $(\%)^{*}$} \\
\hline & Anti-testosterone & Anti-3 $\alpha$-androstanediol \\
\hline 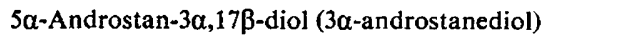 & 4.9 & $100 \cdot 0$ \\
\hline $5 \alpha$-Androstan-17 $\beta$-ol-3-one ( $5 \alpha$-dihydrotestosterone) & 34.6 & $100 \cdot 0$ \\
\hline 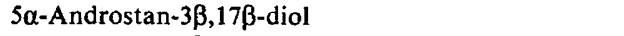 & $5 \cdot 2$ & $50 \cdot 0$ \\
\hline 4-Androsten-17 $\beta$-ol-3-one (testosterone) & $100 \cdot 0$ & $80 \cdot 0$ \\
\hline 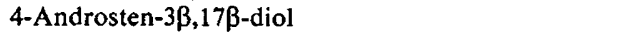 & 0.8 & $15 \cdot 7$ \\
\hline $5 \alpha$-Androstan-3 $\alpha$-ol-17-one (androsterone) & $<0 \cdot 1$ & $1 \cdot 2$ \\
\hline 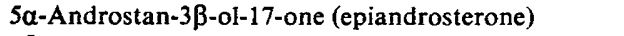 & $<0 \cdot 1$ & $2 \cdot 2$ \\
\hline $5 \beta$-Androstan-3 $\alpha$-ol-17-one (etiocholanolone) & $<0.1$ & $0 \cdot 1$ \\
\hline $5 \alpha$-Androstan-3,17-dione & $2 \cdot 3$ & $2 \cdot 0$ \\
\hline 4-Androsten-3,17-dione (androstenedione) & $<0 \cdot 1$ & $1 \cdot 0$ \\
\hline 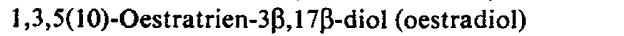 & $<0 \cdot 1$ & $47 \cdot 8$ \\
\hline
\end{tabular}

* Defined as $100 x / y$ where $x$ is the mass of unlabelled testosterone or $3 \alpha$-androstanediol and $y$ is the mass of the heterologous compound required to produce $50 \%$ inhibition of the binding of tritiated steroid by the antibody.

steroids present. Aliquots of this solution were then subjected to two separate radioimmunoassays, one with antiserum relatively specific for testosterone, and the other with a more general specificity for the 17 $\beta$-hydroxyl group (Table 1). The testosterone antibody was raised in rabbits against testosterone-3-oxime-BSA (Purvis, Illius \& Haynes, 1974) whilst the latter was raised in rabbits to $5 \alpha$ androstan-17 $\beta$-ol-3 $\alpha$-hemisuccinate (Steraloids, Pauling, USA) conjugated to BSA. The antiserum to $3 \alpha$-androstanediol exhibited significant cross-reaction to testosterone, $5 \alpha$-dihydrotestosterone, and $3 \alpha$ - and $3 \beta-5 \alpha$-reduced diols, but that to testosterone bound mainly testosterone and $5 \alpha$-dihydrotestosterone (Table 1). Details of the radioimmunoassay procedure and preparation of the phosphate buffer are provided by Brenner, Guerrero, Cekan \& Diczfalusy (1973) and Purvis, Brenner, Landgren, Cekan \& Diczfalusy (1975). Intra-assay and inter-assay coefficients of variation rarely exceeded 5.0 and $8.0 \%$ respectively, and water blanks were negligible.

\section{Assay of individual androgens}

In one experiment which compared the responsiveness to hCG of Leydig cell suspensions prepared from the testes of rats aged $30,40,50,60$ or 80 days, the incubation proceeded for $4 \mathrm{~h}$ without sampling. The incubation medium from the hCG-stimulated cells $(2 \mathrm{ml})$ was then centrifuged and used for the determination of testosterone, androstenedione, $5 \alpha$-dihydrotestosterone and $3 \alpha$-androstanediol by the methods described by Purvis, Calandra, Haug \& Hansson (1977). Briefly, after the addition of ${ }^{3} \mathrm{H}$-labelled internal standards, $1.0 \mathrm{ml}$ medium was extracted twice with $1.0 \mathrm{ml}$ diethyl ether. After evaporation of the solvent phase, the steroid residue was redissolved in $1.0 \mathrm{ml}$ iso-octane and chromatographed on celite micro-columns. The isolated steroids were then subjected to radioimmunoassay. The quantities of different androgens produced were expressed as a percentage of the total quantities of all four androgens.

\section{Results}

The testicular responses of rats of different ages were compared on the basis of the maximum quantity of steroid secreted, the absolute hCG-stimulated increase in steroid secretion $(\Delta)$ and the percentage increase after exposure to hCG for $4 \mathrm{~h}$.

\section{Incubation of decapsulated testes}

The results are shown in Text-fig. 1 and summarized in Table 2. When testosterone was used as the response parameter a substantial increase in the apparent responsiveness of the testes to hCG was 
Table 2. Summary of age-dependent changes (see Text-fig. 1) in responsiveness of decapsulated rat testes to hCG $(3 \mathrm{ng} / 2 \mathrm{ml})$ in vitro

\begin{tabular}{|c|c|c|c|c|c|c|}
\hline \multirow[b]{3}{*}{$\begin{array}{c}\text { Age } \\
\text { (days) }\end{array}$} & \multicolumn{6}{|c|}{ Response parameter (mean \pm s.d.) } \\
\hline & \multicolumn{3}{|c|}{ Testosterone } & \multicolumn{3}{|c|}{$17 \beta$-Hydroxy androgens } \\
\hline & $\begin{array}{c}\text { Maximum* } \\
\text { (ng) }\end{array}$ & $\begin{array}{l}\Delta \dagger \\
(\mathrm{ng})\end{array}$ & $\% \ddagger$ & $\begin{array}{l}\text { Maximum* } \\
\text { (ng) }\end{array}$ & $\begin{array}{c}\Delta \dagger \\
\text { (ng) }\end{array}$ & $\% \ddagger$ \\
\hline 30 & $26 \pm 5$ & $19 \pm 4$ & $733 \pm 8$ & $561 \pm 60$ & $510 \pm 22$ & $1120 \pm 5$ \\
\hline 40 & $55 \pm 11$ & $46 \pm 7$ & $454 \pm 14$ & $821 \pm 180$ & $770 \pm 27$ & $2089 \pm 4$ \\
\hline 60 & $328 \pm 70$ & $292 \pm 17$ & $779 \pm 8$ & $1048 \pm 141$ & $888 \pm 10$ & $655 \pm 12$ \\
\hline 80 & $619 \pm 40$ & $482 \pm 21$ & $449 \pm 19$ & $951 \pm 101$ & $631 \pm 26$ & $302 \pm 18$ \\
\hline
\end{tabular}

* The maximum quantity of steroid produced in response to hCG after incubation for $4 \mathrm{~h}$.

$\dagger$ Absolute change in steroid produced after $4 \mathrm{~h}$ in response to hCG relative to basal levels.

$\$$ Percentage change in steroid produced after $4 \mathrm{~h}$ in response to hCG relative to basal levels.

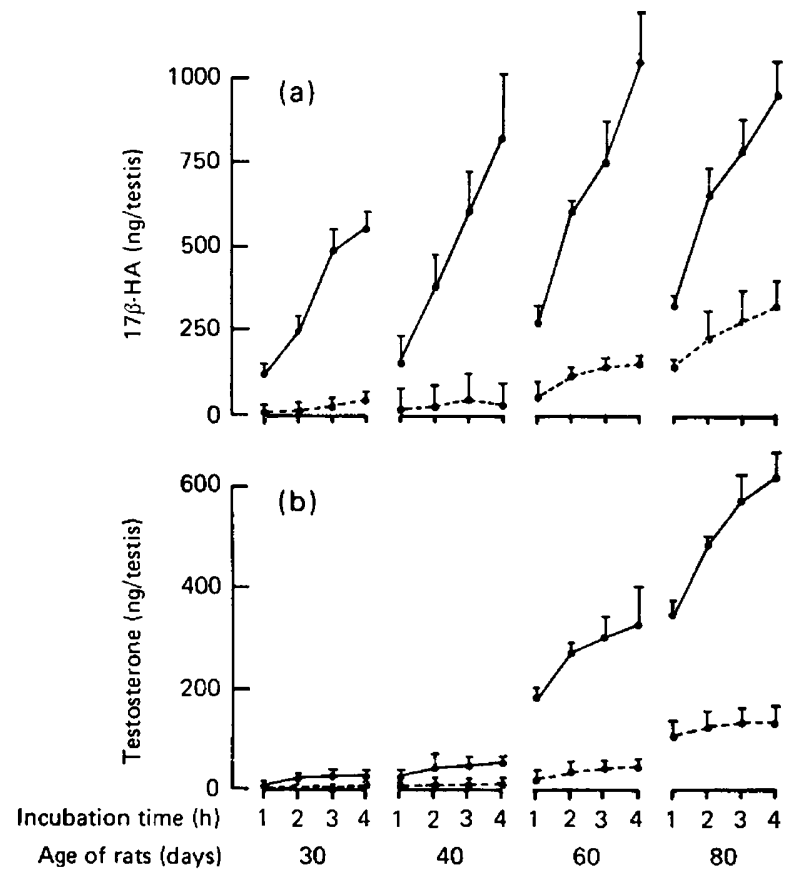

Text-fig. 1. In-vitro response (mean \pm s.d.) to hCG $(3 \mathrm{ng} / 2 \mathrm{ml})$ of decapsulated testes from rats of different ages (5/group, i.e. 10 testes) in terms of production of (a) total 17 3 -hydroxy androgens (17 $\beta$-HA) and (b) testosterone. Broken line represents basal secretion by unstimulated testes.

observed with increasing age, particularly between Days 40 and 60 . However, when Leydig cell secretory activity was assessed by using $17 \beta-\mathrm{HA}$ production, the age differences in response were much less; maximum steroid secretion and $\Delta$ were only marginally increased whilst the percentage changes in secretion were reduced.

Basal secretion of $17 \beta$-HA and testosterone by the decapsulated testes increased 6-fold and 20 -fold respectively between Days 30 and 80 .

\section{Incubation of Leydig cell suspensions}

Increasing age was associated with a gradual increase in the capacity of the individual Leydig cell to secrete testosterone in response to hCG (Table 3, Text-fig. 2a). However, this apparent increase coincided with a gradual decreased secretion of 17 $\beta$-HA (Table 3, Text-fig. $2 b$ ). 
Table 3. Summary of age-dependent changes (see Text-fig. 2) in responsiveness of isolated rat Leydig cell suspensions to $\mathrm{hCG}(3 \mathrm{ng} / 2 \mathrm{ml})$ in vitro

\begin{tabular}{|c|c|c|c|c|c|c|c|}
\hline \multirow[b]{3}{*}{$\begin{array}{l}\text { Data expressed per } \\
10^{6} \text { cells }\end{array}$} & \multirow[b]{3}{*}{$\begin{array}{l}\text { Age } \\
\text { (days) }\end{array}$} & \multicolumn{6}{|c|}{ Response parameter* } \\
\hline & & \multicolumn{3}{|c|}{ Testosterone } & \multicolumn{3}{|c|}{ 17ß-Hydroxy androgens } \\
\hline & & $\underset{(\mu g)}{\operatorname{Max} .}$ & $\stackrel{\Delta}{(\mu g)}$ & $\%$ & $\begin{array}{l}\text { Max. } \\
(\mu g)\end{array}$ & $\underset{(\mu g)}{\Delta}$ & $\%$ \\
\hline Interstitial cells & $\begin{array}{l}30 \\
40 \\
50 \\
60\end{array}$ & $\begin{array}{l}0.06 \\
0.15 \\
0.15 \\
0.14\end{array}$ & $\begin{array}{l}0.05 \\
0.13 \\
0.12 \\
0.12\end{array}$ & $\begin{array}{l}570 \\
838 \\
580 \\
648\end{array}$ & $\begin{array}{l}1.08 \\
0.73 \\
0.29 \\
0.15\end{array}$ & $\begin{array}{l}1.03 \\
0.63 \\
0.22 \\
0.12\end{array}$ & $\begin{array}{r}2193 \\
719 \\
395 \\
510\end{array}$ \\
\hline $\begin{array}{l}\text { Morphological Leydig } \\
\text { cells }\end{array}$ & $\begin{array}{l}30 \\
40 \\
50 \\
60\end{array}$ & $\begin{array}{l}0.08 \\
0.14 \\
0.22 \\
0.37\end{array}$ & $\begin{array}{l}0.06 \\
0.13 \\
0.16 \\
0.31\end{array}$ & $\begin{array}{l}558 \\
953 \\
581 \\
644\end{array}$ & $\begin{array}{l}1.27 \\
0.69 \\
0.43 \\
0.40\end{array}$ & $\begin{array}{l}1.21 \\
0.60 \\
0.32 \\
0.32\end{array}$ & $\begin{array}{r}2191 \\
715 \\
394 \\
517\end{array}$ \\
\hline $3 \beta$-HSD-positive cells & $\begin{array}{l}30 \\
40 \\
50 \\
60\end{array}$ & $\begin{array}{l}0.23 \\
0.39 \\
0.48 \\
1.06\end{array}$ & $\begin{array}{l}0.19 \\
0.36 \\
0.40 \\
0.89\end{array}$ & $\begin{array}{l}557 \\
923 \\
649 \\
645\end{array}$ & $\begin{array}{l}4.41 \\
1.88 \\
0.97 \\
1.15\end{array}$ & $\begin{array}{l}4.21 \\
1.63 \\
0.73 \\
0.92\end{array}$ & $\begin{array}{r}2174 \\
718 \\
397 \\
515\end{array}$ \\
\hline
\end{tabular}

* For details consult Table 2.

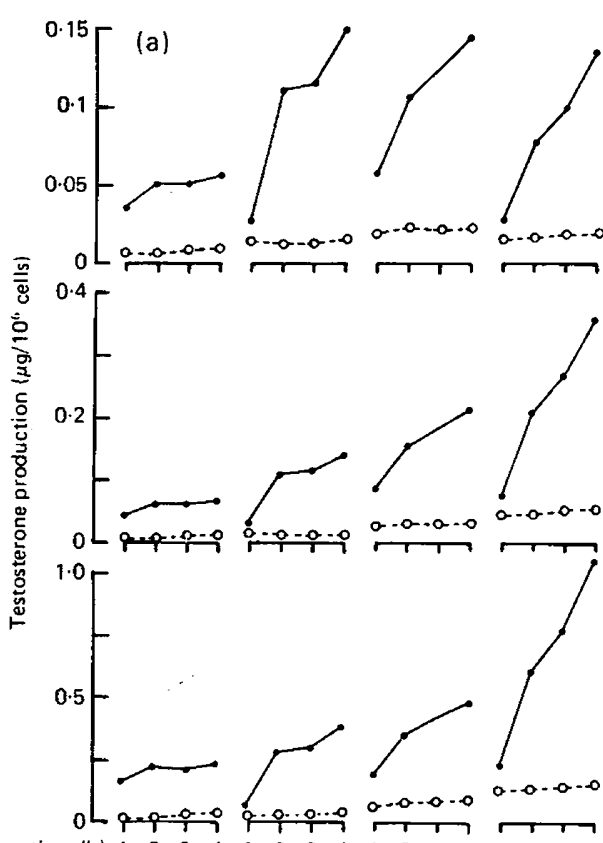

Incubation time (h) $\begin{array}{lllllllllllllllll}1 & 2 & 3 & 4 & 1 & 2 & 3 & 4 & 1 & 2 & 3 & 4 & 1 & 2 & 3 & 4\end{array}$

Age of rats (days) 30

50

60

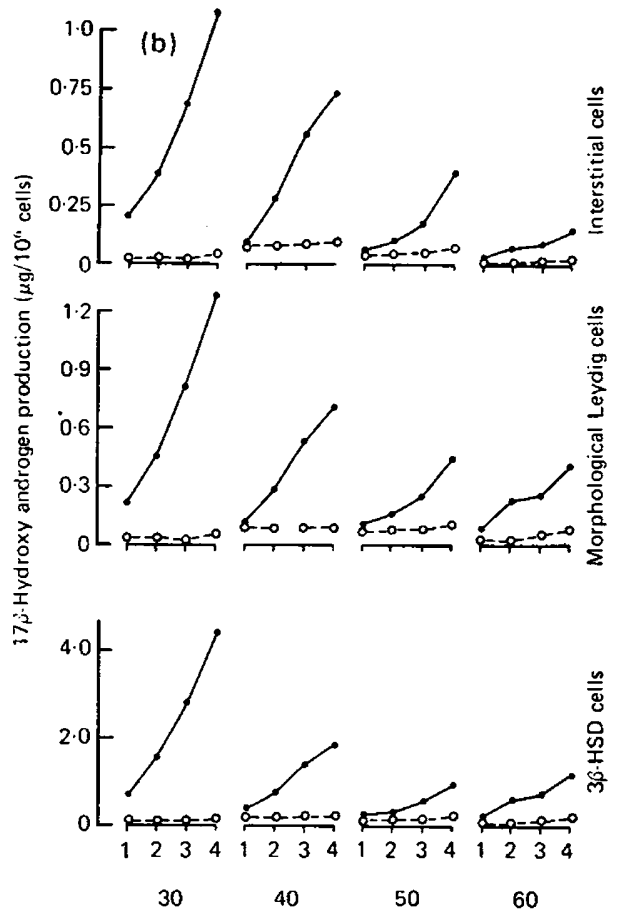

Text-fig. 2. In-vitro response of isolated Leydig cell suspensions from rats aged $30,40,50$ or 60 days to hCG $\left(3 \mathrm{ng} / 2 \mathrm{ml}\right.$ ). Pooled suspensions were prepared from 6 testes. Responses are expressed per $10^{6}$ interstitial cells, per $10^{6}$ morphological Leydig cells and per $10^{6} 3 \beta$-hydroxysteroid dehydrogenase (3 $\beta$-HSD)-positive cells for (a) testosterone and (b) $17 \beta$-hydroxy androgen. Broken line represents basal secretion by unstimulated testes. 


\section{Assay of individual androgens}

The relative proportions of the androgens secreted by isolated Leydig cells from rats of different ages are shown in Text-fig. 3. It is clear that increasing age was associated with a gradual reversal of the contributions of $3 \alpha$-androstanediol and testosterone.

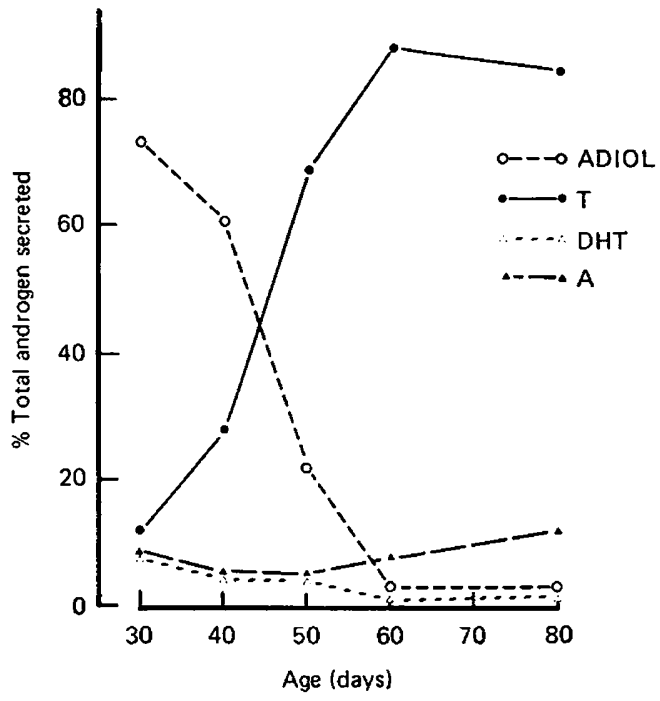

Text-fig. 3. Relative quantities of $5 \alpha$-androstan-3 $\alpha, 17 \beta$-diol (ADIOL), testosterone (T), $5 \alpha$-dihydrotestosterone (DHT) and androstenedione (A) produced by isolated Leydig cell suspensions from 30- to 80-day-old rats $4 \mathrm{~h}$ after exposure to $3 \mathrm{ng}$ hCG.

Table 4. In-vitro response (mean \pm s.d.) to hCG $(3 \mathrm{ng} / 2 \mathrm{ml})$ of decapsulated testes from 30 -day-old rats hypophysectomized 5 days before ( 5 testes/group) in terms of testosterone and $17 \beta$-hydroxy androgen (17ß-HA) production (ng/testis)

\begin{tabular}{lcccc}
\hline & \multicolumn{4}{c}{ Incubation time (h) } \\
\cline { 2 - 5 } Steroid & 1 & 2 & 3 & 4 \\
\hline Testosterone & & & & \\
$\quad$ Basal & $0.69 \pm 0.24$ & $0.68 \pm 0.27$ & $0.51 \pm 0.17$ & $0.48 \pm 0.28$ \\
After hCG & $0.68 \pm 0.28$ & $1.34 \pm 0.37$ & $2.12 \pm 0.29$ & $2.66 \pm 0.18$ \\
17ß-HA & & & & \\
Basal & $0.89 \pm 0.31$ & $0.82 \pm 0.17$ & $0.82 \pm 0.24$ & $0.94 \pm 0.31$ \\
After hCG & $0.83 \pm 0.26$ & $5.91 \pm 2.42$ & $16.51 \pm 5.31$ & $29.32 \pm 10.92$ \\
\hline
\end{tabular}

\section{Response of decapsulated testes from hypophysectomized, immature rats}

This is shown in Table 4. The quantities of testosterone secreted after exposure to hCG were very low but the testes were still able to respond markedly to hCG by secreting 17ß-HA. Although the absolute quantity of $17 \beta-\mathrm{HA}$ secreted was less than $10 \%$ of that produced by the testes of normal 30 -day-old rats (Table 2), the percentage change in 17 $\beta$-HA secretion induced by hCG $(3000 \%)$ still revealed a relatively high degree of responsiveness. 


\section{Discussion}

The present studies show that it is difficult to assess the responsiveness of rat Leydig cells to hCG during prepubertal development because of (1) the marked alteration in the steroids secreted due to the differing degrees of testosterone metabolism to $5 \alpha$-reduced androgens; (2) problems of expression of the data; and (3) the changes of Leydig cell number.

Comparisons of the responses of Leydig cells to hCG stimulation can be made by determination of differences in (i) the absolute change $(\Delta)$ in androgen secretion, (ii) the percentage change of stimulated secretion above basal secretion, and (iii) the maximum quantity of steroids produced during the experimental period. Each gives slightly different information about Leydig cell function and, when used alone, permits only a limited appreciation of the functional changes which may be involved. It is for this reason that Leydig cell response to hCG was expressed in all three ways in the present study. The maximum quantity of androgen produced after incubation for $4 \mathrm{~h}$ provides an indication of the steroidogenic capacity, but not the responsiveness of the testis, e.g. a testis may secrete relatively large quantities of steroid in vitro but exhibit little if any response to hCG, as in the feminized male rat (Purvis, Clausen \& Hansson, 1978). The relative change in secretion from basal to stimulated levels, expressed either in absolute terms $(\Delta)$ or as a percentage, is a parameter which is more clearly related to hCG stimulation and should therefore provide a measure of responsiveness. However, both expressions are influenced to a large extent by the level of basal secretion, i.e. an extremely low or high basal production caused by drug or hormone treatment in vivo may exaggerate or underestimate the apparent responsiveness of the testes in vitro.

The extensive metabolism of testosterone in the testes of prepubertal rats renders it unsuitable as a response parameter for monitoring hCG/LH effects on the Leydig cell in animals less than about 50 days of age. The present study shows that the relative quantities of testosterone secreted by the Leydig cells of 30- and 40-day-old rats are extremely low when compared to those of older animals. The major secretory product of the immature rat testis is $3 \alpha$-androstanediol, an observation which confirms the results of many earlier studies on testosterone metabolism in which tracer techniques were used (Nayfeh et al., 1966; Strickland et al., 1970; Coffey et al., 1971 ; Ficher \& Steinberger, 1971 ; Matsumoto \& Yamada, 1973). These studies showed that, between about 25 and 45 days of age, much of the testosterone produced by the rat Leydig cell was metabolized into $5 \alpha$-reduced steroids, especially $3 \alpha$-androstanediol, because of the stimulation of $5 \alpha$-reductase in the testis (Nayfeh, Coffey, Hansson \& French, 1975; van der Molen, Grootegoed, de Greef-Bijleveld, Rommerts \& van der Vusse, 1975). In agreement with these findings, our present results demonstrate that between Days 40 and 50 the activity of $5 \alpha$-reductase is apparently diminished and that testosterone is the major steroid secreted. Our finding that hCG stimulated the production of $3 \alpha$-androstanediol by isolated Leydig cell suspensions from immature rat testes confirms previous work (van der Molen et al., 1975) which suggested that the major site of the metabolism of testosterone to $5 \alpha$-reduced androgens is the Leydig cell and not the seminiferous tubule, as has been suggested by others (Rivarola, Podesta, Chemes \& Cigorraga, 1975). The fact that age-related changes in the steroid metabolizing enzymes of the testis can alter Leydig cell secretion qualitatively, but not necessarily quantitatively, emphasizes that it may not be appropriate to compare Leydig cell function at different ages by using only a single component of secretion as the response parameter.

There are several reports of an increase in the size of the Leydig cell population in the rat testes before puberty, but the magnitude of the change varies from 2-3-fold (Clegg, 1966; Knorr, VanhaPerttula \& Lipsett, 1970) to 10-fold (Pahnke, Leidenberger \& Künzig, 1975) between Days 30 and 60. It is probable therefore that the small differences in 17ß-HA produced by the decapsulated testes of immature and mature rats in our study can easily be accounted for by an increase in the number of Leydig cells per testis. If the change is as great as 10-fold (Pahnke et al., 1975), hCG responsiveness and the quantities of steroid produced by each Leydig cell would be decreasing rather than increasing with age. The increase in the size of the basal secretion of 17ß-HA from decapsulated testes in vitro may reflect changes in the size of the Leydig cell population or differences in the extent to which the testes have been exposed to endogenous LH before removal, or both. The fact that the differences in basal secretion disappear when equal numbers of Leydig cells are compared (Text-fig. 3) suggests that the 
former alternative is more likely. The steroidogenic capacity and responsiveness to hCG in vitro decreased gradually from Days 30 to 60 when the data were expressed for equal numbers of Leydig cells. This decline may reflect a reduced availability of precursors or cofactors or a reduction in the number of available hCG/LH receptors. Studies are currently in progress to elucidate the mechanisms involved.

This work was supported by grants from the World Health Organisation, the Norwegian Society for Fighting Cancer and the Norwegian Research Council for Science and the Humanities. We thank M. Purvis and A. Schjölberg for skilled technical assistance, and L. Stöttum for typing the manuscript.

\section{References}

Brenner, P.F., Guerrero, R., Cekan, Z. \& Diczfalusy, E. (1973) Radioimmunoassay method for six steroids in human plasma. Steroids 22, 775-794.

Clausen, O.P.F., Purvis, K. \& Hansson, V. (1978) Assessment by microflow fluorometry of the purity of interstitial cell suspensions from the rat testis. $J$. Reprod. Fert. 52, 387-390.

Clegg, E.J. (1966) Pubertal growth in the Leydig cells and accessory reproductive organs of the rat.J. Anat. 100, 369-379.

Coffey, J.C., French, F.S. \& Nayfeh, S.N. (1971) Metabolism of progesterone by rat testicular homogenates. IV. Further studies of testosterone formation in immature testis in vitro. Endocrinology 89, 865-872.

Ficher, M. \& S teingerger, E. (1971) In-vitro progesterone metabolism by rat testicular tissue at different stages of development. Acta endocr., Copenh. 68, 285-292.

KNORR, D.W., VANha-Perttula, T. \& Lipsett, M.B. (1970) Structure and function of rat testis through pubescence. Endocrinology 86, 1298-1304.

Levy, H., DeAne, H.W. \& Rubin, B.L. (1959) Visualization of steroid-3 $\beta$-ol-dehydrogenase activity in tissues of intact and hypophysectomized rats. Endocrinology 65, 932-943.

Matsumoto, K. \& Yamada, M. (1973) $5 \alpha$-Reduction of testosterone in vitro by rat seminiferous tubules and whole testes at different stages of development. Endocrinology 93, 253-255.

MOYLE, W.R. \& RAMACHANDRAN, J. (1973) Effect of LH on steroidogenesis and cyclic AMP accumulation in rat Leydig cell preparations and mouse tumor Leydig cells. Endocrinology 93, 127-134.

NAyfeh, S.N., BAREFOOT, S.W., JR \& BAggetT, B. (1966) Metabolism of progesterone by rat testicular homogenates II. Changes with age. Endocrinology 78, 1041-1048.

Nayfeh, S.N., Coffey, J.C., Hansson, V. \& French, F.S. (1975) Maturational changes in testicular steroidogenesis : hormonal regulation of $5 \alpha$ reductase. J. Steroid Biochem. 6, 329-335.

Odell, W.D. \& SwerdLoFF, R.S. (1975) The role of testicular sensitivity to gonadotropins in sexual maturation of the male rat. J. Steroid Biochem. 6, 853-857.

Odell, W.D., SWerdloff, R.S., Bain, J., Wollesen, F. \& Grover, P.K. (1974) The effect of sexual maturation on testicular response to $\mathrm{LH}$ stimulation of testosterone secretion in the intact rat. Endocrinology 95, 1380-1384.

Pahnkf, V.G., Leidenberger, F.A. \& Künzig, H.J. (1975) Correlation between HCG (LH)-binding capacity, Leydig cell number and secretory activity of rat testis throughout pubescence. Acta endocr., Copenh. $79,610-618$.

Payne, A.H., Kelch, R.P., Murono, E.P. \& Kerlan, J.T. (1977) Hypothalamic, pituitary and testicular function during sexual maturation of the male rat. $J$. Endocr. 72, 17-26.

Purvis, K., Brfnner P.F., Landgren, B.-M., Cekan, Z. \& DiczFalusy, E. (1975) Indices of gonadal function in the human male. 1. Plasma levels of unconjugated steroids and gonadotrophins under normal and pathological conditions. Clin. Endocr. 4, 237-246.

Purvis, K., Calandra, R., Haug, E. \& Hansson, V. (1977) $5 \alpha$ reduced androgens and testicular function in the immature rat. Effects of $5 \alpha$-androstan-17 $\beta$-ol3-one (DHT) propionate and $5 \alpha$-androstan-3 $\alpha, 17 \beta-$ diol. Mol. cell. Endocr. 7, 203-219.

Purvis, K., Cl.ausen, O.P.F. \& Hansson, V. (1978) Decreased Leydig cell responsiveness in the testicular feminized male rat. Endocrinology (in press).

Purvis, K., Illius, A.W. \& Haynes, N.B. (1974) Plasma testosterone concentrations in the ram. J. Endocr. 61, 241-253.

Rivarola, M.A., Podesta, E.J., Chemes, H.E. \& Cigorraga, S. (1975) Androgen metabolism in the seminiferous tubule. In Hormonal Regulation of Spermatogenesis, pp. 25-35. Eds F. S. French, V. Hansson, E. M. Ritzén \& S. N. Nayfeh. Plenum Press, New York.

Steinberger, E. \& Ficher, M. (1968) Conversion of progesterone to testosterone by testicular tissue at different stages of maturation. Steroids 11, 351-368.

Strickland, A.L., NAYFeh, S.N. \& FrenCh, F.S. (1970) Conversion of cholesterol to testosterone and androstanediol in testicular homogenates of immature and mature rats (1). Steroids 15, 373-387.

VAN DER MOlen, H.J., Grootegoed, J.A., DE GreeFBirleveld, M.J., Rommerts, F.F.G. \& VAN DER Vusse, G.J. (1975) Distribution of steroids, steroid production and steroid metabolizing enzymes in rat testis. In Hormonal Regulation of Spermatogenesis, pp. 3-23. Eds F. S. French, V. Hansson, E. M. Ritzén \& S. N. Nayfeh. Plenum Press, New York. 